Eine möglichst frühzeitige und absolute Ruhigstellung der frakturierten Extremität, schonende Lagerung und baldige stabile Druckplattenosteosynthese nach einigen Tagen konservativer Behandlung sind neben einer ausreichenden Volumensubstitution und Flüssigkeitszufuhr wohl die wichtigsten Maßnahmen zur Verhütung von Serumlipidveränderungen bei der Osteosynthese. Bei polytraumatisierten Patienten sollten die Osteosynthesen erst nach absoluter Beherrschung der mittels Thrombocytenzählung erkennbaren Verbrauchskoagulopathie vorgenommen werden.

\title{
293. Dauerhaft heparinisierte, nicht thrombocyten-affine plastische Oberflächen
}

\author{
H. LagergreN* und J. C. ERIKsson-Stockholm/Schweden
}

\section{Permanently Heparinised Plastic Coatings without Thrombocyte Affinity}

Summary. A simple method for the manufacture of stable, heparinised plastic coatings has been developed. The plastic material is first cleaned and subsequently brought in contact with 4 different, circulated and heated solutions of octadecyliminprophylamine hydrochloride, heparin, glutardialdehyde and $25 \% \mathrm{NaCl}$. The heparinised coating is exceedingly stable and does not dissolve in blood, as was demonstrated with S-35-labelled heparin. The coating can be sterilised with ethylene oxide or gamma irradiation. Fresh blood preserved in polyethylene or polypropylene test-tubes treated in this way was still fluid after $24 \mathrm{~h}$. It clotted after the normal time when transferred to a glass test tube. Specially designed arterio-venous shunts heparinised according to this method were still patent after $12 \mathrm{~h}$ whereas untreated shunts of identical construction clotted in $15 \mathrm{~min}$.

Zusammenfassung. Eine einfache Methode der Herstellung von stabil heparinisierten Plastik-Oberflächen wurde entwickelt. Das Plastikmaterial wurde zunächst gereinigt und dann anschließend mit vier verschiedenen zirkulierten und erhitzten Lösungen von Octadecyliminprophylaminhydrochloride, Heparin, Glutardialdehyde und $25 \%$ Kochsalz in Kontakt gebracht.

Die heparinisierte Oberfläche ist ausgezeichnet stabil und löst sich nicht in Blut auf. Dieses wurde mit S-35 markiertem Heparin nachgewiesen. Die Oberflächen können mit Ethylen oxid oder Gamma-Bestrahlung sterilisiert werden.

Frisches Blut, das in so behandelten Teströhrchen aus Polyethylen oder Polypropylen aufbewahrt wurde, war noch nach $24 \mathrm{Std}$ flüssig. Es gerann in normaler Zeit, wenn es im Teströhrchen aus Glas übergeführt wurde. Nach einer besonderen Methode ausgeführte heparinisierte arteriovenöse Shunts waren noch nach 12 Std offen, wohingegen unbehandelte Shunts derselben Bauart nach 15 min verstopften. 